\title{
CSR Communication through Social Media: A Litmus Test for Banking Consumers' Loyalty
}

\author{
Naveed Ahmad ${ }^{1, * \mathbb{C}}$, Rana Tahir Naveed ${ }^{2}$, Miklas Scholz ${ }^{3,4,5, * \mathbb{C}}$, Muhammad Irfan ${ }^{6}$, Muhammad Usman ${ }^{2}$ \\ and Ilyas Ahmad ${ }^{2}$
}

1 Faculty of Management Studies, University of Central Punjab, Lahore 54000, Pakistan

2 Department of Economics and Business Administration, Art \& Social Sciences

Division, University of Education, Lahore 54000, Pakistan; tahir.naveed@ue.edu.pk (R.T.N.); m.usman@ue.edu.pk (M.U.); ilyas.ahmad@ue.edu.pk (I.A.)

3 Department of Building and Environmental Technology, Division of Water Resources Engineering, Faculty of Engineering, Lund University, P.O. Box 118, 22100 Lund, Sweden

4 Civil Engineering Research Group, School of Science, Engineering and Environment, The University of Salford, Newton Building, Salford M5 4WT, UK

5 Department of Town Planning, Engineering Networks and Systems, South Ural State University (National Research University), 76, Lenin prospekt, 454080 Chelyabinsk, Russia

6 Institute of Banking and Finance, Bahauddin Zakariya University, Multan 66000, Pakistan; dr.mirfan@bzu.edu.pk

* Correspondence: naveeddgk2010@gmail.com (N.A.); miklas.scholz@tvrl.lth.se (M.S.)

Citation: Ahmad, N.; Naveed, R.T.; Scholz, M.; Irfan, M.; Usman, M.; Ahmad, I. CSR Communication through Social Media: A Litmus Test for Banking Consumers' Loyalty. Sustainability 2021, 13, 2319.

https://doi.org/10.3390/su13042319

Academic Editor: Andrea Pérez

Received: 2 February 2021

Accepted: 13 February 2021

Published: 20 February 2021

Publisher's Note: MDPI stays neutral with regard to jurisdictional claims in published maps and institutional affiliations.

Copyright: (c) 2021 by the authors. Licensee MDPI, Basel, Switzerland. This article is an open access article distributed under the terms and conditions of the Creative Commons Attribution (CC BY) license (https:// creativecommons.org/licenses/by/ $4.0 /)$.

\begin{abstract}
Prior literature in the field of corporate social responsibility (CSR) has largely focused on investigating its relationship with organizational-related outcomes, whereas the impact of CSR on consumer behavior is largely ignored in the recent literature. Further, most of the prior studies have investigated CSR with a philanthropic viewpoint, but its importance in achieving marketing-related outcomes is something that is to date, underexplored. Hence, the aim of the present study is to investigate the impact of CSR communication through social media on consumer loyalty with the mediating effect of consumers' brand admiration in the banking sector of Pakistan. The banking sector was selected due to the reason that this sector is homogenized in nature and creating consumers' loyalty due to this homogenized character of this sector is challenging. The data of the present study were collected from different banking consumers through an adapted questionnaire on a five-point Likert scale. A total of 448 fully filled questionnaires were received which included 289 male and 159 female banking consumers. The results of the present study revealed that CSR communications through social media have a positive impact on consumer loyalty, and consumers' brand admiration partially mediates this relationship. The findings of the present study would help policymakers from banking institutions to use CSR strategy from the perspective of marketing which is undoubtedly very important for every organization in the current digital age.
\end{abstract}

Keywords: social media; CSR; admiration; consumer loyalty; sustainability

\section{Introduction}

The development in communication technologies has forced organizations to use new communication strategies to deliver their important messages to different stakeholders including consumers [1]. Research has long established that traditional communication channels and strategies are losing their effectiveness with the rise of social media in today's digital age. Thus, businesses are pushed to be involved in the conversation with consumers through social media. Social media offer organizations the opportunities to deliver their CSR messages and stories with different stakeholders [2]. The main advantage of social media includes its wide availability to diverse stakeholders in a short period of time through using different social media platforms, such as Twitter, Facebook, Instagram, YouTube and others. The organizations may share their stories and videos to convince the 
stakeholders about their contributions to the wellbeing of the consumers and their families, as well as to the lives of the consumers, the shareholders, the environment and the society as a whole. Another advantage of social media over traditional communication strategies is its ability to provide interactive communication to the organizations. The organizations can offer their services to the stakeholders and receive immediate feedback and can discuss with the stakeholders to establish better relationships [3].

According to stakeholder theory, not only do the organization's shareholders emphasize the importance of social responsibility for the sustainable growth of the organizations, but other stakeholders, including consumers, suppliers, governments, environmental organizations, non-governmental organizations and local communities also acknowledge its importance [4]. Freeman et al. [5] described the stakeholders as "a group and persons benefiting or harmed, as well as persons whose rights have been violated or respected due to the organizational business activities". This means that different people have their own positions in collective actions, so organizations must be accountable for satisfying their needs and rights in a socially responsible manner. Organizations are not only accountable to their shareholders, but they are also answerable to their stakeholders with diverse interests in the organization.

Social media have emerged as a powerful and effective tool for sustainable business communication [6]. Most of the people around the world use social media for communication and information sharing purpose. Hence, people can use such media to create content or express their opinions about corporate characteristics or ethics [7]. Social media are a source to share information that can be disseminated in a short time to a larger community. It is also used by the organizations to deliver their messages, as well as to attract various stakeholders and to maintain competition in the digital age [8]. Statistics show that about 3.6 billion individuals were using social media in 2020 [9]. Given the importance of the social media in modern communications, organizations communicate important messages through social media. It is claimed that media services produced by unpaid communities such as consumers have the potential to change the mindset of general audience and create a good brand image for a specific brand [10].

The organization's use of social media is also important to communicate corporate social responsibility (CSR) activities. Different studies have highlighted the importance of using social media for effective CSR communication because the communication from different social media platforms is considered to be more transparent and can better shape the behavior of consumers to support sustainability objectives of an organization $[1,3]$. By engaging in corporate social responsibility (CSR) activities, organizations not only provide feedback but also create supportive environment for different stakeholders [7]. Hence, the aim of the present study is to investigate the impact of CSR communication through social media on consumers' outcomes such as consumer loyalty and consumer brand admiration in the banking sector of Pakistan. The present study contends that CSR communication through social media develops positive emotions among consumers, in the shape of consumers' brand admiration, which in turn affects their loyalty towards a particular brand.

This is evident from the recent literature that businesses are required to incorporate CSR in their business decisions in order to meet the expectations of different stakeholders and to build a better brand image [11]. However, this perspective is largely ignored by contemporary CSR researchers as most of the studies related to CSR largely focused on firm-centric outcomes to be achieved through CSR initiatives [12,13]. Consumers prefer organizations that perform CSR functions, and modern organizations realize the importance of CSR communication to shaping consumer behavior positively. The ecology-related information to society and consumers via environmental advertising raises the awareness level of consumers and other stakeholders, and they urge organizations to practice sustainability in a real sense [14]. Moreover, sustainability has emerged as one of the most important concerns for modern businesses [15]. Likewise, Abbas et al. [16] noted the positive effect of CSR on consumer behavior. Therefore, a general link between CSR activities 
and consumer behavior is logical to consider, and different studies have also identified a positive link between CSR and consumer purchasing intentions [17,18]. Organizations with appropriate CSR policies have good consumer preferences. In relation to consumers, Brown and Dacin [19] identified two types of CSR activities which include association and participation. Association refers to consumers' understanding of corporate ethics in social matters, and participation speaks about the level at which they participate in the implementation of CSR plans with organizations. For example, Hur et al. [20] noted the importance of a socially responsible profile of an organization in defining consumer commitments and to achieve organizational objectives. This means that the higher the level of CSR engagement of an organization, the greater the willingness of consumers to contribute to the achievement of the sustainability goals of an organization. CSR collaboration and consumer services are critical for achieving community-based outcomes [21]. The development and maintenance of sustainable relationships between business and consumers through effective communication, identification, discussion and exchange processes, or a combination of these factors, are critical for achieving sustainable organizational objectives. Similarly, Zasuwa [22] analyzed the impact of CSR participation on consumer behavior and concluded that CSR activities increase the level of consumer involvement with the organization. Businesses that work to improve the well-being of consumers and their families have better relationships with their consumers, which in turn show a higher level of commitment with the organization. Shareholders and prospective investors also recognize the importance of the CSR [23]. The prior literature also acknowledged the association between CSR communication and favorable consumer behavior [24,25]. The main purpose of entrepreneurs' coverage of their CSR services on social media is to attract the attention of different stakeholders [26]. For example, if CSR initiatives are properly delivered to consumers, it is expected that such initiatives will positively impact consumer behavior [27]. The literature provides ample evidence to the positive impact of CSR initiatives on consumer behavior in different countries and in different business areas [28,29].

Prior studies on the topic of CSR have largely investigated the impact of CSR activities on financial outcomes of an organization $[30,31]$ but the potential impact of CSR on consumer-centric outcomes, such as on loyalty and on positive emotions, has been largely missed by contemporary CSR researchers. These consumers-related outcomes of CSR are very important for any organization to base their competitive advantage on solid foundations [32]. Likewise, there have been some studies on the topic of CSR and consumer behavior $[33,34]$, but how CSR is related to emotional outcomes (such brand admiration) and attitudinal outcomes (loyalty) is underexplored in recent literature.

The contributions of the present study are critical for existing CSR and consumer behavior literature for the following reasons. First, the prior literature has largely focused on cognitive aspect of consumer behavior [35-37], whereas the emotional side of consumer behavior has been rarely explored in existing literature. We, in this regard, argue that although cognitive side of consumer behavior is important, the emotional side of individuals is far more effective in shaping positive consumer behavior in comparison to the cognitive one. Hence, we build an argument in this study that well-planned CSR communications of an organization may generate a sense of brand admiration among consumers (emotional aspect of behavior) and they feel admiration for that organization that practices CSR proactively. This argument receives support from existing literature [38,39]. Ultimately these emotions (admiration) build a higher level of loyalty among consumers, which is very important for any organization.

Secondly, the banking sector of Pakistan is purposefully chosen for the present study because this sector is facing a high level of competition and retaining the existing consumers is of utmost importance to each bank in this sector $[40,41]$. However, the problem with the banking sector of Pakistan, as with other developing regions of the world, is that the character of the banking sector is homogenized in nature, where mostly banks offer, more or less, the same kinds of products/services to the consumers, which creates the challenge of how to hold the current share of consumers and how to uphold their loyalty level so that 
there is less likelihood of consumers' switching to other brands. In this connection, CSR may be a good strategy in the context of marketing objectives because CSR initiatives of a bank create positive emotions (admiration) in consumers to stay connected with a bank, which in turn takes them towards a higher level of loyalty.

Thirdly, different researchers in recent studies have argued that the phenomenon of CSR and consumer loyalty are complex to understand, and their relationship is better explained in the presence of moderator(s) and mediator(s) [42,43]. Hence, we have logically introduced the consumers' brand admiration as a mediating variable between the relationship of CSR communication through social media and consumer loyalty. Lastly, the majority of prior research studies have been conducted in developed countries [44,45]; we argue here that as the concept of CSR is contextual in nature and produces different results in different contexts, it will not be logical to generalize the results from developed countries in the context of developing countries. The remainder of this article is arranged as follows: the second part of the present study discusses the literature review, the third section is concerned with methodology, the fourth section is about results and the analysis phase, and finally the last section includes the discussion and implications of the present study.

\section{Theoretical Framework}

Over the years, CSR has emerged as one of the most popular strategies in the business world. CSR is defined as "an honest business practice that helps sustain economic development by working with employees, their families, local organizations and the general public to improve their living conditions" [46]. This research study defines CSR in line with the definition of founding father Carroll [47] in the field of CSR, who defines it as "CSR is the economic, legal, ethical and philanthropic obligation of a business towards society". In his definition, the first set (economic, legal) is required by society, and the second set (ethical, philanthropic) is expected by society.

CSR aims to reduce the environmental impact of organizations along with the wellbeing of employees, their families, consumers and society [48]. The main business principle in CSR is to effectively seek business opportunities, strengthen relationships with the community and solve common societal problems. In the recent era, businesses are facing social, political and economic changes that encourage the growth of a new culture in the organizations. Globalization along with technological development also contributes to the emergence of a new social model with new actors and behaviors. New questions and expectations about the management, communications and social responsibility have been emerging in the present era [49]. As a result, many companies in all industries understand the importance of their role in the society for developing a successful CSR model because they know the benefits of doing business in line with CSR philosophy. For example, companies can make significant profits from one of the CSR beneficiary groups, such as consumers [17].

In recent times, the concept of sustainability has emerged as a "new normal" for modern businesses [50] in which sustainable practices are not only concerned with the philanthropic orientation of an organization, but these practices are also important from a marketing point of view. For example, modern consumers are well aware of the importance of sustainability for a better and sustainable future, and they consider it while making purchase decisions [51]. Marketers need to realize the importance of sustainability for attaining consumer preferences towards their brand, and hence they need to incorporate this element of sustainability into their marketing communication objectives [52]. This argument of incorporating sustainability into marketing communication is also supported by Nyilasy et al. [53] who mentioned that green advertising enhances consumer purchase intentions.

The present study uses the lens of attribution theory as a grounding theory. The theory was originally proposed by Fritz [54] and further advanced by Kelley [55]; the theory investigates how people explain the causes of behaviors and events. Attribution theory has been heavily exercised in consumer behavior studies [56-58]. In the context 
of the present study, we argue that attribution process influence consumers' evaluation of a brand based on their CSR perceptions for that brand. Hence, the higher the level of consumers' evaluation of a brand to be labeled as a socially responsible brand, the greater the likelihood that consumer will prefer that brand over competitors [59]. By portraying the image of a socially responsible organization, businesses can increase loyal consumers by turning consumers into business ambassadors and advocating consultants due to their sense of admiration in response to well-planned CSR initiatives and communicating with stakeholders of an organization. For instance, this can lead to positive word-of-mouth communications for their admired organization, willingness to pay premium prices and less consideration of the rival brands [60]. It should be noted that CSR communication tools are very important in providing CSR messages and building the image of a socially responsible organization. In addition to company experience, in high-end products and models, socially responsible organizations receive empowerment from different stakeholders including consumers and reflect compliance with issues that are distinctive from the usual cultural norms. The main challenge in developing a CSR approach is to involve consumers and other stakeholders for reducing their uncertainty in achieving sustainable organizational goals [61].

Recent CSR research has shown that engaging stakeholders in CSR programs allows companies to build a strong image [62], strengthen consumer relationships [16] and improve the reputation of businesses [63]. Hence, CSR activities inculcate the feelings of admiration among consumers as they are admired being the customers of an organization that is socially responsible and actively contributes to uplift society and the environment [38]. Ultimately, this sense of admiration takes them towards a higher level of loyalty [64]. Providing accurate CSR information to stakeholders not only increases their participation in the organization, but also promotes the company's representation on different social media platforms [65]. Advances in technology have changed the way businesses use CSR planning and its implementation.

Social media platforms expand communication and collaboration between groups of individuals. It also promotes the quick dissemination of information, and it is a tool that allows people to express their ideas and communicate with others; people can come up with new ideas and use them to improve organizational approach in building a sustainable environment [66]. There have also been different studies highlighting the importance of CSR communication to the stakeholders using conventional media [67-69], acknowledging that CSR communication with stakeholders has positive outcomes for an organization. However, the rise of social media is the dawn of a new horizon in the field of marketing communication [70,71]. In particular, social media can be categorized into two categories, such as expressive and collaborative. Expressive social media include sites such as blogs, Twitter, YouTube, Facebook and Flickr, and collaborative social media include sites such as Wikipedia and Craigslist. Social media have changed the future of businesses due to its low cost, wider range and interactive environment which attracts companies to use it for advertising, consumer marketing or consumer company communication. Instead, the consumer role is changing with the rise of social media technologies [72]. Dwivedi et al. [73] contended that consumers' brand attachment on social media positively impacts consumerbased brand equity.

Consumers are no longer recognized as an isolated entity, as they are well-concerned and connected with the organizations from which they purchase their products or services. They not only have the knowledge needed to make a decision, but also provide important feedback to organizations for improving the overall performance of their products in line with the philosophy of sustainability [74]. Social media are a powerful communication tool for disseminating information on CSR-related activities, seeking strong links between socially responsible organization and consumers and attracting partners through in-depth reviews on products' performance [75]. In brief, social media are a powerful modern tool for informing consumers about CSR initiatives of an organization. 
The present study introduces the construct of consumer sense of brand admiration as a potential mediator between CSR communication on social media and consumer loyalty and defines this as "consumer brand admiration is the process that involves consumers with a brand personally through evoking positive emotions, trust, love and respect". This definition is also supported by eminent contemporary researchers such as Park et al. [76] and Trivedi and Sama [77]. The reason to think about consumer brand admiration as a potential mediator lies in the logic that when consumers are informed about the social responsibility of an organization they develop positive emotions on their part for that organization and start associating them with the brand positively, all this in turn takes consumers towards a higher level of loyalty. Further, the present study defines consumer loyalty in line with the definition of Oliver [78] who contends that consumer loyalty is a tendency of consumers to prefer a brand in the long run over its competitors.

Prior literature has also recognized that well-planned CSR plans in the context of the banking sector are associated with positive emotions of consumers [42,79]. It is also established in the recent literature that positive emotions, such as feelings of admiration, are positively related to consumer loyalty $[80,81]$. To summarize, we conclude that the rise of social media has changed the traditional business model that was a sort of one way communication model, as the emergence of social media has been highly acknowledged by the organizations and consumers due to its flexibility, broader range, quick dissemination of information and, above all, its interactive communicative options. The consumers, in this regard, behave like ambassadors of an organization through their positive word-ofmouth communications toward an admired organization; all such activities inculcate a higher level of loyalty in the consumers. Hence based upon above discussion, we argue that CSR activities directly and indirectly (through brand admiration) are associated with consumer loyalty. Therefore, the following set of hypotheses is framed. Further, the proposed relations of the studied variables are framed in Figure 1 for the readers.

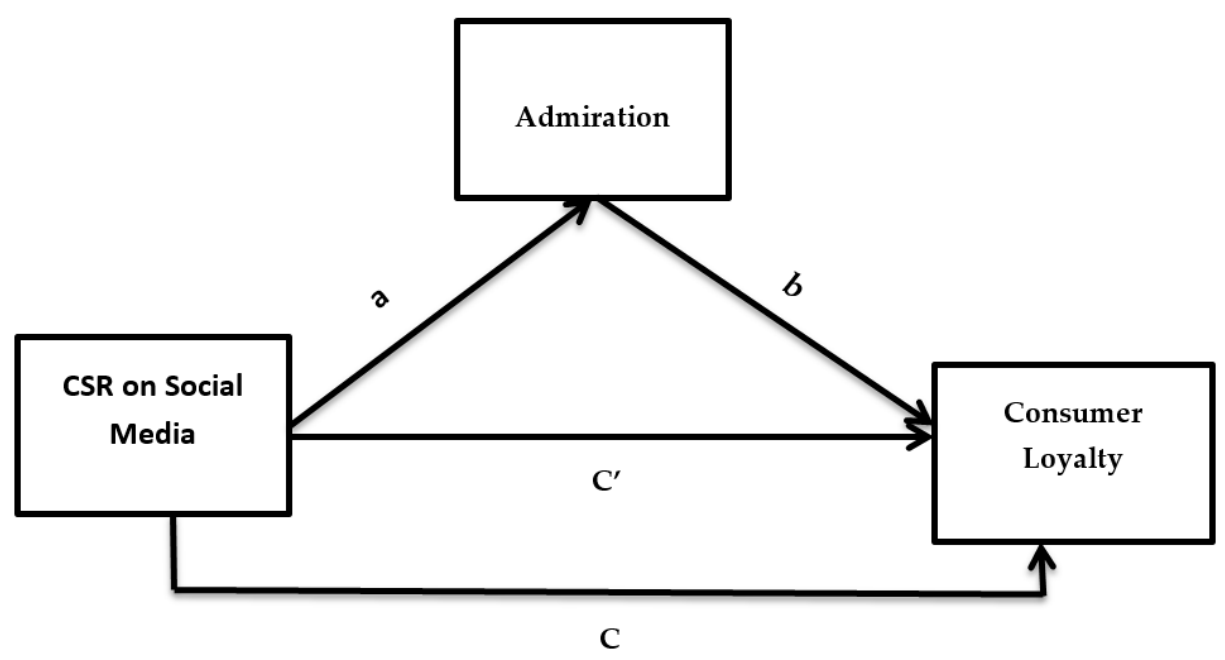

Figure 1. Proposed research model showing path directions for mediation. Where corporate social responsibility $(\mathrm{CSR})(\mathrm{X})=$ the independent variable, consumer loyalty $(\mathrm{Y})=$ the dependent variable, admiration $(\mathrm{M})=$ the mediating variable, $\mathrm{a}^{*} \mathrm{~b}=$ the indirect effect of the mediator on $\mathrm{Y}$, and $C^{\prime}=$ indirect direct effect of $X$ on $Y$ with the effect of the mediator, $C=$ direct effect of $X$ on $Y$ without mediator.

Hypothesis 1 (H1). CSR communications of a bank through social media are positively related to consumer loyalty.

Hypothesis 2 (H2). CSR communications of a bank through social media are positively related to consumers' brand admiration. 
Hypothesis 3 (H3). Consumers' brand admiration mediates the relationship between CSR communication through social media and consumer loyalty.

\section{The Data Collection and Measures}

The proposed model of the present study is intended to be tested on banking consumers. The banking sector for the present study was selected due to two specific reasons. First, due to the homogenized character of the banking industry, it is very difficult to differentiate the services of a bank from its competitors in order to gain consumers' attention. Second, the banking sector of Pakistan is facing a stiff competitive environment where the ordinary strategies for consumer retention might not be helpful, and hence some extraordinary thinking is necessary to address the situation on the part of policymakers and marketers from the banking institutions.

The rise of a second wave of the COVID-19 pandemic posed some serious challenges on the data collection phase of the present study due to smart lockdown in different regions of the country. Likewise, it was also not feasible for us to maintain physical contact with the consumers of different banks in order to invite them to participate in the survey. In this regard, an online survey was the only option that could work for the present study in the context of data collection. Before disseminating the questionnaire online, we carefully assessed the banking institutions of Pakistan which were actively involved in CSR initiatives. We came out with a list of four banks named Habib Bank Limited (HBL), United Bank Limited (UBL), MCB Bank Limited and Allied Bank Limited (ABL). The selection of these banks was made as these banks are the four largest banks in the country with widespread branches all over the country; furthermore, all these banks have their CSR presence on social media (Facebook, YouTube and Twitter, etc.). To start with the data collection phase, we prepared an online self-administered survey and sent it to different individuals through emails and WhatsApp. The online survey includes two screening questions regarding the CSR knowledge of the respondents and whether they have a bank account in any of these four banks. We initially floated 1000 surveys to different individuals for the purpose of data collection. As was expected, the online strategy of data collection resulted in a poor response rate as we received only 116 questionnaires from respondents; among those 116 surveys we had to discard 11 questionnaires because they were partially filled and could not be included into final dataset because these contained missing information on the part of respondent, and researchers were unable to address these kind of questionnaires. Thus, we deleted these questionnaires and recorded 105 questionnaires in our first phase of data collection. This strategy is in line with the guidelines of Ahmed et al. [82]. We started the second phase of the online survey using the same procedure as in the previous phase. This time, we received 118 filled questionnaires. Our repeated efforts and poor response rate pushed us to start another phase of data collection; this time, we invited our colleagues and peers to support us in data collection process by using their personal contacts. We sent the online questionnaire to our colleagues with this request to share it with their fellows through email and WhatsApp and asked them to fill in the questionnaire. This strategy eventually worked for us, and we were able to collect a feedback of 448 respondents (105 in the first phase, 118 in the second and 225 in the last phase). We used already established scales for measuring our study variables: for example, we adapted the items for CSR from the studies of van Asperen et al. [83] and Eisingerich et al. [84]. The scale consisted of five items; likewise, the items of brand admiration were adapted from Sweetman et al. [85]. This scale consisted of a total of five items. Lastly, the three-item scale of consumer loyalty was adapted from Dagger et al. [86]. We used a five-point Likert scale for recording the responses from respondents.

\section{Results}

\subsection{Common Method Bias, Sample Profile, Validity and Reliability}

As the data for all variables of the present study were collected from the same individuals, there is a likelihood for the presence of common method bias (CMB) in our data. 
In order to handle $\mathrm{CMB}$, we followed the guidelines of [81], and we performed a single factor confirmatory factor analysis in AMOS. The results revealed a poor model fit which means that there was no single dominating factor in our data. This is a positive symbol because it pushes away the fear of common method bias from our data. Hence, we took the data analysis phase at further levels. We in this regard, first of all presented the descriptive statistics of our sample (Table 1).

Table 1. Demographic profile.

\begin{tabular}{ccc}
\hline & Frequency & $\%$ \\
\hline Gender & 289 & \\
Male & 159 & 64.5 \\
Female & & 35.5 \\
Age & 49 & \\
$18-20$ & 169 & 10.9 \\
$21-30$ & 112 & 37.7 \\
$31-40$ & 76 & 25.1 \\
$41-45$ & 42 & 17.0 \\
Above 45 & 53 & 09.3 \\
Education & 129 & 11.8 \\
Intermediate & 176 & 28.8 \\
Graduate & 90 & 39.3 \\
Master & 20.1 \\
Higher & &
\end{tabular}

Next, we performed a factor analysis in order to observe whether all items of a variable have acceptable factor loadings greater than 0.5 (See Table 2). The empirical results revealed that all the items having factor loadings greater than the cut-off value of 0.5 ; hence, we established that all items are well-loaded onto their respective variable. Similarly, the results of standard deviation (SD) for all variables are also described in Table 2. All values for SD analysis are fewer than 1 and closer to 0 ; that means there is less variability in our data which is good as less variability means that our data are close to mean values.

Table 2. Correlations, validities and reliabilities.

\begin{tabular}{|c|c|c|c|c|c|c|c|}
\hline Variables & Mean & SD & CSR & $\mathrm{AD}$ & CL & MSV & ASV \\
\hline CSR & 3.41 & 0.51 & $(0.781)$ & $0.213^{* *}$ & $0.409 * *$ & 0.186 & 0.163 \\
\hline $\begin{array}{l}\text { Admiration } \\
\text { (AD) }\end{array}$ & 3.85 & 0.46 & & $(0.818)$ & $0.362 * *$ & 0.142 & 0.118 \\
\hline Loyalty (CL) & 3.79 & 0.38 & & & $(0.842)$ & 0.109 & 0.087 \\
\hline & Items & Loadings * & AVE & $\alpha$ & CR & Skewness & Kurtosis \\
\hline CSR & 5 & $0.65-0.77$ & 0.61 & 0.76 & 0.76 & -0.72 & 0.39 \\
\hline $\mathrm{AD}$ & 5 & $0.74-0.89$ & 0.67 & 0.82 & 0.83 & -0.33 & 0.28 \\
\hline CL & 3 & $0.63-0.81$ & 0.71 & 0.87 & 0.89 & -0.18 & 0.23 \\
\hline
\end{tabular}

Loadings *: Factor loading range (max: min); $\alpha$ : Cronbach's $\alpha$ coefficient; CR: composite reliability; AVE: average variance extracted; **: significant values of correlations; MSV: maximum shared variance; ASV: average shared variance. The bold diagonal values represent square root of AVE for a variable.

Next, we report the results of correlation analysis amongst the study variables. According to the results, all three variables are positively related to each other: for example, the value of correlation amongst CSR and brand admiration is $0.213^{* *}$, which is significant and positive, meaning that these two variables are correlated positively. The bold diagonal values in the table (Table 2) present the results of discriminant validity values; in doing so, we calculated the square root values of average variance extracted (AVE) for each variable and then compared it with the values of correlations of other variables. The rule of thumb is that if square root of AVE is greater than the correlation values, then it is established that 
the items of one variable discriminate with other variable items, and hence discriminant validity of the data is maintained. Table 2 also disuses the results of convergent validity for achieving convergent validity. We calculated AVE of each variable: the AVEs for each variable are larger than 0.5 , which means convergent validity is well-maintained for our instrument. The reliability values (alpha and composite reliabilities) are also reported in Table 2, which are more than 0.70 and prove that the reliability of our instrument is also fine. Lastly, we also reported the results of normality. We, in this regard, are in line with the recommendation of Brown [87], who recommended that the data normality is established when the values of standard deviation (SD) are in the range of \pm 1.5 , skewness \pm 3 and kurtosis \pm 10 . These results establish our confidence to state that there is no issue of data normality in our data. All these measures encourage the researchers to take the data analysis further for hypotheses testing.

In next step of data analysis, we tested model fit indices. Initially we tested model fit index values for each construct individually, which produced good results (CSR: $\chi^{2} / d f=2.81$ RMSEA $=0.054 \mathrm{NFI}=0.943, \mathrm{CFI}=0.949, \mathrm{GFI}=0.946$; Admiration: $\chi^{2} / d f=3.11$ RMSEA $=0.063$ $\mathrm{NFI}=0.928, \mathrm{CFI}=0.930 \mathrm{GFI}=0.928 ;$ Loyalty: $\chi^{2} / d f=2.91=\mathrm{RMSEA}=0.058 \mathrm{NFI}=0.919$, $\mathrm{CFI}=0.927 \mathrm{GFI}=0.922)$ for each variable. Finally, we checked model fit results for our threefactor model that is our hypothesized model too. The model fit results for our three-factor model produced more appropriate results (see Table 3).

Table 3. Model fit indices.

\begin{tabular}{cc}
\hline Variable & Model Fit Indices \\
\hline CSR & $\chi^{2} / d f=2.81$, RMSEA $=0.054, \mathrm{NFI}=0.943, \mathrm{CFI}=0.949, \mathrm{GFI}=0.946$ \\
Admiration & $\chi^{2} / d f=3.11, \mathrm{RMSEA}=0.063, \mathrm{NFI}=0.928, \mathrm{CFI}=0.930 \mathrm{GFI}=0.928$ \\
Loyalty & $\chi^{2} / d f=2.91, \mathrm{RMSEA}=0.058, \mathrm{NFI}=0.919, \mathrm{CFI}=0.927 \mathrm{GFI}=0.922$ \\
Overall model fit (three factor model); $\chi^{2} / d f=2.19 \mathrm{RMSEA}=0.39, \mathrm{NFI}=0.972$, \\
$\mathrm{CFI}=0.981, \mathrm{GFI}=0.978$
\end{tabular}

\subsection{Hypothesis Testing}

We used the structural equation modeling (SEM) technique for hypothesis testing. In this regard, we used AMOS software and we conducted our analysis in two steps. In the first step, we checked the results of direct effects, and in second step we checked the results of mediation analysis. We have reported these results in Table 4. According to these results, the direct effect model suggests that our hypotheses 1 and 2 are true $\left(\mathrm{H} 1 ; \beta=0.277^{* *}\right.$, $\mathrm{LLCI}=0.193, \mathrm{ULCI}=0.374, p<0.05 \mathrm{H} 2 ; \beta=0.198^{* *}, \mathrm{LLCI}=0.490, \mathrm{ULCI}=0.832, p<0.05$ ). Further, for testing the mediation results, we used the bootstrapping option in AMOS software by choosing a larger bootstrap sample of 2000. The results of the mediation analysis showed that the variable "brand admiration" is playing the role of a mediator between CSR and consumer loyalty (H3; $\beta=0.093^{* *}, \mathrm{LLCI}=0.117$, ULCI $=0.367, p<0.05$ ). It is to be noted that the beta value is reduced from $0.198^{* *}$ (direct effect) to $0.093^{* *}$ (indirect effect) which means that there is partial mediation effect of brand admiration between CSR and consumer loyalty. 
Table 4. Hypothesis testing.

\begin{tabular}{|c|c|c|c|c|c|}
\hline Path & Beta Value & S.E & LLCI & ULCI & Decision \\
\hline & \multicolumn{5}{|c|}{ Model 1: Standardized direct effects } \\
\hline $\begin{array}{c}\text { CSR } \rightarrow \\
\text { Admiration }\end{array}$ & $0.277^{* *}$ & 0.039 & 0.193 & 0.374 & Accepted \\
\hline CSR $\rightarrow$ Loyalty & $0.198 * *$ & $\begin{array}{r}0.042 \\
\left(\chi^{2} / d f=1.69, \mathrm{RN}\right. \\
* * * \\
* * \text { be } \\
\text { Model 2: } \mathrm{S}\end{array}$ & $\begin{array}{l}0.490 \\
\mathrm{JFI}=0 \text {. } \\
H 1, R^{2} \\
\text { es for d } \\
\text { cant, } \\
\text { ldirect }\end{array}$ & $\begin{array}{l}0.832 \\
\text {, GFI } \\
\text { del } \\
\text { cant } \\
\text { on mo }\end{array}$ & Accepted \\
\hline $\begin{array}{l}\text { CSR } \rightarrow \\
\text { Admiration } \rightarrow \\
\text { Loyalty }\end{array}$ & \multicolumn{5}{|c|}{$\begin{array}{c}\left(\chi^{2} / d f=1.39, \mathrm{RMSEA}=0.041, \mathrm{NFI}=0.986, \mathrm{CFI}=0.987, \mathrm{GFI}=0.985\right) * * * \\
\left(R^{2}=0.23 * \text { for } H 3\right) \\
* * * \text { model fit indices for mediated (three factor }) \text { model } \\
* * \text { beta value significant, }{ }^{*} R^{2} \text { value significant }\end{array}$} \\
\hline
\end{tabular}

CSR = corporate social responsibility, S.E = standard error, $\mathbf{L L C I}=$ lower limit confidence interval, $\mathbf{U L C I}$ = upper limit confidence interval.

\section{Discussion and Implications}

The present study aims at investigating the impact of CSR communication through social media on consumer loyalty in the context of banking sector of Pakistan with the mediating effect of brand admiration. The results of the present study revealed that CSR initiatives directly and indirectly, via admiration, influence the banking consumers' loyalty. The results further affirmed that the involvement of a bank in CSR communication using social media produces better outcomes for building sustainable image of a bank. These results are also in line with the studies of Aramburu and Pescador [88] and Bediako [89]. When an organization uses social media to communicate its CSR activities with different stakeholders including the consumers, it creates positivity among consumers for that organization which ultimately increases their loyalty. The recent study of Bilgin [10] also acknowledged the importance of social media to enhance brand loyalty.

The rise of social media and information technology has brought a paradigm shift in business communication models. Traditionally, the business communication model was based on one-way communication, but with the rise of the digital age, this one-way communicative model is being replaced with an interactive communication model in which different stakeholders, including consumers, have their voice and say in the business decisions of an organization. Modern consumers are more informative and empowered due to the access of information and availability of different knowledge platforms. Our research affirmed that when consumers see that their bank is communicating its CSR activities on social media with them, it inculcates a sense of admiration among them for the bank, and this sense of admiration actually builds a higher level of loyalty in consumers. Hence the results confirmed that CSR initiatives are positively related with admiration; this finding is also supported by contemporary researchers in their studies [64,90]. Likewise, the mediating role of admiration between the relationship of CSR communication through social media and consumer loyalty is also an important factor in this relationship.

The present study has some important implications for theory and practice. For example, the present study adds to extant CSR literature in the context of consumers, whereas the majority of the previous studies have addressed CSR relation in the organizational context. Likewise, another important theoretical implication of the present study is that it introduces the novel construct of consumers' brand admiration as mediator between the relationship of CSR communication on social media and consumer loyalty. Likewise, the study adds to contemporary literature of CSR from a developing country context where this phenomenon is still underexplored. Further, the present study enriches the extant literature from the perspective of marketing by highlighting that CSR initiatives of an 
organization can be helpful in attaining marketing-related objectives of an organization, including consumer loyalty.

Likewise, the study has some important practical implications: for example, it highlights to the policymakers of banking institutions that looking at CSR from the perspective of marketing may generate better marketing-related outcomes in an industry which is labeled as homogenized and where differentiation of products and services is very difficult. Well-planned CSR activities of a bank may be a key resource that can build a competitive advantage for a specific bank. Currently, the majority of banking institutions of Pakistan are practicing CSR activities with a philanthropic mindset, and they intentionally or unintentionally have ignored the marketing aspect of CSR plans to enhance consumer loyalty. This is the time for the banking institutions of Pakistan to change their approach towards CSR initiatives and think of CSR in terms of consumer-related outcomes. Our study, in this regard, is a pioneering one which highlights the importance of CSR communication through social media for establishing consumer loyalty. Furthermore, the usage of social media for communicating CSR initiatives produces positive emotions on the part of consumer as they feel admiration for an organization that truly practices CSR activities and informs their stakeholders about such initiatives. Ultimately, the consumers become a strong advocate for such organizations and develop positive word-of-mouth communications on social media for the brand. It is noteworthy that when an organization is being promoted by the consumers, it produces better results as compared to advertising outcomes, because the feedback given by consumers to other potential consumers is considered to be honest and transparent. Our results further affirmed that CSR communication on social media is very important for consumer loyalty.

Traditional CSR communication can also affect consumers behavior as mentioned in prior studies $[67,91]$, but the point to note here is that social media are an interactive medium which provides the organizations with a platform to interactively communicate with different stakeholders. In this connection, CSR communication through social media works on the emotional aspects of consumer behavior, which is very strong as compared to the cognitive aspects, because once the consumers develop positive emotions (admiration), they are less price-sensitive and are even willing to pay a premium price to the bank for which they feel admiration. Likewise, such consumers are less likely to switch to the competing brands. The banking institutions are required to work on these new insights from this study in order to place the CSR initiatives as core to their business strategies, with the mindset that CSR is double edged sword as on one hand it addresses the social obligations of a bank towards society, and on the other hand it can create consumer-related outcomes by building higher levels of consumer loyalty and positive emotions.

\section{Limitations and Future Research Directions}

The present study also faces some limitations which may be considered a way forward for future researchers. The first limitation of our study lies in the fact that our target population was only the banking sector, which creates the question of generalizing the results of the present study into other service sectors. In order to address this issue, the future researchers are suggested to test our model in another service sector, such as the insurance and healthcare sectors for better generalizability. Secondly, the data for the present study were cross-sectional, which limits us in establishing any causation effect with confidence. One remedy to answer this issue in future research is to use longitudinal data which are able to provide historical information about the issue at hand, and hence are considered better for establishing causality. Thirdly, the present study only took the perception of consumers for CSR initiatives, whereas it has neglected the inputs from other stakeholder such as employees, who are equally important for an organization. Thus, for future researchers it is suggested examination of the effect of CSR initiatives on employees and assessment of whether properly planned CSR initiatives create positive emotions among employees. Fourthly, the study only considered the impact of CSR communication on consumer loyalty, whereas other important variables such as service quality, trust and 
brand image were not considered to predict banking consumer loyalty. Thus, the future researchers are encouraged to address this issue by considering these variables in our model as a mediator or moderator. Lastly, the influence of age, gender and income are not considered in this research. For future research, testing the possible impact of age, gender and income levels as moderators can be a meaningful extension of this research. Likewise, the present study has investigated the impact of CSR communication through social media on consumer loyalty; future researchers are encouraged to investigate further brand-related variables such as brand equity, which is one of the most cited variables in the field of marketing. It will be interesting for future researchers to investigate which brand equity, consumer based or finance based is the most affected though CSR activities.

Author Contributions: All of the authors contributed to conceptualization, formal analysis, investigation, methodology and writing and editing the original draft. All authors have read and agreed to the published version of the manuscript.

Funding: This research received no external funding.

Institutional Review Board Statement: Not applicable.

Informed Consent Statement: Informed consent was obtained from the respondents of the survey.

Data Availability Statement: The data will be made available on request from the corresponding author.

Acknowledgments: The authors acknowledge Andrijana Markovic for her support and efforts during the publication process of this manuscript.

Conflicts of Interest: The authors declare no conflict of interest.

\section{References}

1. Gomez, L.M. The State of Social Media Research in CSR Communication. The Palgrave Handbook of Corporate Social Responsibility; Springer: Berlin/Heidelberg, Germany, 2020; pp. 1-23.

2. Lund, N.F.; Cohen, S.A.; Scarles, C. The power of social media storytelling in destination branding. J. Destin. Mark. Manag. 2018, 8, 271-280. [CrossRef]

3. Hibbert, S. CSR engagement via social media: In theory and practice. In Communicating Corporate Social Responsibility in the Digital Era; Routledge: London, UK, 2017; pp. 3-16.

4. Waheed, A.; Zhang, Q. Effect of CSR and Ethical Practices on Sustainable Competitive Performance: A Case of Emerging Markets from Stakeholder Theory Perspective. J. Bus. Ethics 2020, 1-19. [CrossRef]

5. Freeman, R.E.; Harrison, J.S.; Wicks, A.C.; Parmar, B.L.; De Colle, S. Stakeholder Theory: The State of the Art; Cambridge University Press: Cambridge, UK, 2010.

6. Hussain, T.; Chen, S.; Nurunnabi, M. The role of social media for sustainable development in mountain region tourism in Pakistan. Int. J. Sustain. Dev. World Ecol. 2019, 26, 226-231. [CrossRef]

7. Wang, R.; Huang, Y. Communicating corporate social responsibility (CSR) on social media. Corp. Commun. Int. J. 2018, 23, 326-341. [CrossRef]

8. Liu, Y.; Jiang, C.; Zhao, H. Assessing product competitive advantages from the perspective of customers by mining user-generated content on social media. Decis. Support. Syst. 2019, 123, 113079. [CrossRef]

9. Statista. Most Popular Social Networks Worldwide as of October 2020, Ranked by Number of Active Users. Available online: https: / www.statista.com/statistics/272014/global-social-networks-ranked-by-number-of-users/ (accessed on 18 December 2020).

10. Bilgin, Y. The effect of social media marketing activities on brand awareness, brand image and brand loyalty. Bus. Manag. Stud. Int. J. 2018, 6, 128-148. [CrossRef]

11. Contini, M.; Annunziata, E.; Rizzi, F.; Frey, M. Exploring the influence of Corporate Social Responsibility (CSR) domains on consumers' loyalty: An experiment in BRICS countries. J. Clean. Prod. 2020, 247, 119158. [CrossRef]

12. Latif, K.F.; Sajjad, A.; Bashir, R.; Shaukat, M.B.; Khan, M.B.; Sahibzada, U.F. Revisiting the relationship between corporate social responsibility and organizational performance: The mediating role of team outcomes. Corp. Soc. Responsib. Environ. Manag. 2020, 27, 1630-1641. [CrossRef]

13. Sarkar, S.; Chatterjee, M.; Bhattacharjee, T. Does CSR disclosure enhance corporate brand performance in emerging economy? Evidence from India. J. Indian Bus. Res. 2021. [CrossRef]

14. Casado-Aranda, L.-A.; Martínez-Fiestas, M.; Sánchez-Fernández, J. Neural effects of environmental advertising: An fMRI analysis of voice age and temporal framing. J. Environ. Manag. 2018, 206, 664-675. [CrossRef] [PubMed]

15. Ahmad, N.; Mahmood, A.; Han, H.; Ariza-Montes, A.; Vega-Muñoz, A.; Din, M.u.; Iqbal Khan, G.; Ullah, Z. Sustainability as a “New Normal" for Modern Businesses: Are SMEs of Pakistan Ready to Adopt It? Sustainability 2021, 13, 1944. [CrossRef] 
16. Abbas, M.; Gao, Y.; Shah, S.S.H. CSR and customer outcomes: The mediating role of customer engagement. Sustainability 2018, 10, 4243. [CrossRef]

17. Sharma, V.; Jeannne, P.; Mohanta, S.; Liza, E. Influence of the dimensions of CSR activities on consumer purchase intention. Innov. Mark. 2018, 14, 23-32. [CrossRef]

18. Kim, J.S.; Song, H.; Lee, C.-K.; Lee, J.Y. The impact of four CSR dimensions on a gaming company's image and customers' revisit intentions. Int. J. Hosp. Manag. 2017, 61, 73-81. [CrossRef]

19. Brown, T.J.; Dacin, P.A. The company and the product: Corporate associations and consumer product responses. J. Mark. 1997, 61, 68-84. [CrossRef]

20. Hur, W.M.; Kim, H.; Kim, H.K. Does customer engagement in corporate social responsibility initiatives lead to customer citizenship behaviour? The mediating roles of customer-company identification and affective commitment. Corp. Soc. Responsib. Environ. Manag. 2018, 25, 1258-1269. [CrossRef]

21. Phillips, S.; Thai, V.V.; Halim, Z. Airline Value Chain Capabilities and CSR Performance: The Connection Between CSR Leadership and CSR Culture with CSR Performance, Customer Satisfaction and Financial Performance. Asian J. Shipp. Logist. 2019, 35, 30-40. [CrossRef]

22. Zasuwa, G. The role of company-cause fit and company involvement in consumer responses to CSR initiatives: A meta-analytic review. Sustainability 2017, 9, 1016. [CrossRef]

23. Kim, M.; Kim, Y. CSR and shareholder value in the restaurant industry: The roles of CSR communication through annual reports. Cornell Hosp. Q. 2019, 60, 69-76. [CrossRef]

24. Tarabashkina, L.; Tarabashkina, O.; Quester, P. Using numbers in CSR communication and their effects on motive attributions. J. Consum. Mark. 2020, 37, 855-868. [CrossRef]

25. Schramm-Klein, H.; Zentes, J.; Steinmann, S.; Swoboda, B.; Morschett, D. Retailer corporate social responsibility is relevant to consumer behavior. Bus. Soc. 2016, 55, 550-575. [CrossRef]

26. She, C.; Michelon, G. Managing stakeholder perceptions: Organized hypocrisy in CSR disclosures on Facebook. Crit. Perspect. Account. 2019, 61, 54-76. [CrossRef]

27. Dunn, K.; Harness, D. Communicating corporate social responsibility in a social world: The effects of company-generated and user-generated social media content on CSR attributions and scepticism. J. Mark. Manag. 2018, 34, 1503-1529. [CrossRef]

28. Kim, J.; Lacey, R.; Kim, H.-R.; Suh, J. How CSR serves as a preventive mechanism for coping with dysfunctional customer behavior. Serv. Bus. 2019, 13, 671-694. [CrossRef]

29. Karaosmanoglu, E.; Altinigne, N.; Isiksal, D.G. CSR motivation and customer extra-role behavior: Moderation of ethical corporate identity. J. Bus. Res. 2016, 69, 4161-4167. [CrossRef]

30. Karyawati, G.; Subroto, B.; Sutrisno, T.; Saraswati, E. Explaining the complexity relationship of CSR and financial performance using neo-institutional theory. J. Asian Bus. Econ. Stud. 2020, 27, 227-244.

31. Ramzan, M.; Amin, M.; Abbas, M. How does corporate social responsibility affect financial performance, financial stability, and financial inclusion in the banking sector? Evidence from Pakistan. Res. Int. Bus. Financ. 2021, 55, 101314. [CrossRef]

32. Ahmad, N.; Scholz, M.; Ullah, Z.; Arshad, M.Z.; Sabir, R.I.; Khan, W.A. The nexus of CSR and co-creation: A roadmap towards consumer loyalty. Sustainability 2021, 13, 523. [CrossRef]

33. Shah, S.S.A.; Khan, Z. Creating advocates: Understanding the roles of CSR and firm innovativeness. J. Financ. Serv. Mark. 2021, 1-12. [CrossRef]

34. Fatma, M.; Khan, I.; Rahman, Z. CSR and consumer behavioral responses: The role of customer-company identification. Asia Pac. J. Mark. Logist. 2018, 30, 460-477. [CrossRef]

35. Wang, T. Social identity dimensions and consumer behavior in social media. Asia Pac. Manag. Rev. 2017, 22, 45-51. [CrossRef]

36. Conner, S.L.; Reardon, J.; Miller, C.; Salciuviene, L.; Auruskeviciene, V. Cultural antecedents to the normative, affective, and cognitive effects of domestic versus foreign purchase behavior. J. Bus. Econ. Manag. 2017, 18, 100-115. [CrossRef]

37. Chen, C.-C.; Chen, C.-W.; Tung, Y.-C. Exploring the consumer behavior of intention to purchase green products in belt and road countries: An empirical analysis. Sustainability 2018, 10, 854. [CrossRef]

38. Castro-González, S.; Bande, B.; Fernández-Ferrín, P.; Kimura, T. Data to model the influence of CSR on consumer behaviors: A process approach. Data Brief 2019, 27, 104713. [CrossRef] [PubMed]

39. Linacre, S. Status symbols: How to win admiration and influence people. Ann. Soc. Responsib. 2019, 5, $2-4$.

40. Saleem, M.A.; Zahra, S.; Ahmad, R.; Ismail, H. Predictors of customer loyalty in the Pakistani banking industry: A moderatedmediation study. Int. J. Bank Mark. 2016, 34, 411-430. [CrossRef]

41. Rafay, A.; Franco, G.; Gilani, U. Measuring Competition in Banking Industry: Evidence from Latin American Economies. Pak. Bus. Rev. 2019, 21, 154-163.

42. Raza, A.; Saeed, A.; Iqbal, M.K.; Saeed, U.; Sadiq, I.; Faraz, N.A. Linking corporate social responsibility to customer loyalty through co-creation and customer company identification: Exploring sequential mediation mechanism. Sustainability 2020, 12, 2525. [CrossRef]

43. Sun, H.; Rabbani, M.R.; Ahmad, N.; Sial, M.S.; Cheng, G.; Zia-Ud-Din, M.; Fu, Q. CSR, Co-Creation and Green Consumer Loyalty: Are Green Banking Initiatives Important? A Moderated Mediation Approach from an Emerging Economy. Sustainability 2020, 12, 10688. [CrossRef]

44. Bagozzi, R.; Grappi, S.; Romani, S. Consumers Reactions to Admirable or Reprehensible Corporate Behavior. Proc. Eur. Mark. Acad. 2020, 49, 1-10. 
45. Castro-González, S.; Bande, B.; Fernández-Ferrín, P.; Kimura, T. Corporate social responsibility and consumer advocacy behaviors: The importance of emotions and moral virtues. J. Clean. Prod. 2019, 231, 846-855. [CrossRef]

46. Siltaoja, M.E. Value priorities as combining core factors between CSR and reputation-A qualitative study. J. Bus. Ethics 2006, 68, 91-111. [CrossRef]

47. Carroll, A.B. The pyramid of corporate social responsibility: Toward the moral management of organizational stakeholders. Bus. Horiz. 1991, 34, 39-48. [CrossRef]

48. Brondoni, S.M.; Bosetti, L.; Civera, C. Ouverture de 'CSR and Multi-Stakeholder Management'. Symph. Emerg. Issues Manag. 2019, 1, 1-15. [CrossRef]

49. Chu, S.-C.; Chen, H.-T. Corporate social responsibility (CSR) communication in social media in china: The role of identification with the company and brand trust. In American Academy of Advertising. Conference. Proceedings (Online); American Academy of Advertising: Heathrow, FA, USA, 2017; p. 177.

50. Jose, R.; Ramakrishna, S. Comprehensiveness in the Research on Sustainability; Springer: Berlin/Heidelberg, Germany, 2021.

51. Li, M.; Hua, Y.; Zhu, J. From Interactivity to Brand Preference: The Role of Social Comparison and Perceived Value in a Virtual Brand Community. Sustainability 2021, 13, 625. [CrossRef]

52. Lee, Y.C. Communicating sustainable development: Effects of stakeholder-centric perceived sustainability. Corp. Soc. Responsib. Environ. Manag. 2020, 27, 1540-1551. [CrossRef]

53. Nyilasy, G.; Gangadharbatla, H.; Paladino, A. Perceived greenwashing: The interactive effects of green advertising and corporate environmental performance on consumer reactions. J. Bus. Ethics 2014, 125, 693-707. [CrossRef]

54. Fritz, H. The Psychology of Interpersonal Relations; John Wiley and Sons: New York, NY, USA, 1958.

55. Kelley, H.H. Attribution theory in social psychology. In Nebraska Symposium on Motivation; University of Nebraska Press: Lincoln, NE, USA, 1967.

56. Chakraborty, U.; Bhat, S. The effects of credible online reviews on brand equity dimensions and its consequence on consumer behavior. J. Promot. Manag. 2018, 24, 57-82. [CrossRef]

57. Jackson, M. Utilizing attribution theory to develop new insights into tourism experiences. J. Hosp. Tour. Manag. 2019, 38, 176-183. [CrossRef]

58. Sharma, T. What a Waste: Confronting Consumer Food Waste Behavior in Hospitality Settings. In Advances in Hospitality and Leisure; Emerald Publishing Limited: Bentley, UK, 2021.

59. Ginder, W.; Kwon, W.-S.; Byun, S.-E. Effects of Internal-External Congruence-Based CSR Positioning: An Attribution Theory Approach. J. Bus. Ethics 2019, 1-15. [CrossRef]

60. Chomvilailuk, R.; Butcher, K. Evaluating the effect of corporate social responsibility communication on mobile telephone customers. J. Retail. Consum. Serv. 2016, 33, 164-170. [CrossRef]

61. Lee, E.-M.; Yoon, S.-J. The effect of customer citizenship in corporate social responsibility (CSR) activities on purchase intention: The important role of the CSR image. Soc. Responsib. J. 2018, 14, 753-763. [CrossRef]

62. Ramesh, K.; Saha, R.; Goswami, S.; Dahiya, R. Consumer's response to CSR activities: Mediating role of brand image and brand attitude. Corp. Soc. Responsib. Environ. Manag. 2019, 26, 377-387. [CrossRef]

63. Tetrault Sirsly, C.-A.; Lvina, E. From doing good to looking even better: The dynamics of CSR and reputation. Bus. Soc. 2019, 58, 1234-1266. [CrossRef]

64. Mohammed, A.; Al-Swidi, A. The influence of CSR on perceived value, social media and loyalty in the hotel industry. Span. J. Mark. ESIC 2019, 23, 373-396. [CrossRef]

65. Dutot, V.; Galvez, E.L.; Versailles, D.W. CSR communications strategies through social media and influence on e-reputation. Manag. Decis. 2016, 54, 363-389. [CrossRef]

66. Reilly, A.H.; Hynan, K.A. Corporate communication, sustainability, and social media: It's not easy (really) being green. Bus. Horiz. 2014, 57, 747-758. [CrossRef]

67. Kim, S.; Ferguson, M. Public expectations of CSR communication: What and how to communicate CSR. Public Relat. J. 2014, 8, 1-22.

68. Andreu, L.; Casado-Díaz, A.B.; Mattila, A.S. Effects of message appeal and service type in CSR communication strategies. J. Bus. Res. 2015, 68, 1488-1495. [CrossRef]

69. Birth, G.; Illia, L.; Lurati, F.; Zamparini, A. Communicating CSR: Practices among Switzerland's top 300 companies. Corp. Commun. Int. J. 2008, 13, 182-196. [CrossRef]

70. Hogan, M.; Strasburger, V.C. Social media and new technology: A primer. Clin. Pediatrics 2018, 57, 1204-1215. [CrossRef]

71. Subramanian, K.R. Influence of social media in interpersonal communication. Int. J. Sci. Prog. Res. 2017, $38,70-75$.

72. Ketonen-Oksi, S.; Jussila, J.J.; Kärkkäinen, H. Social media based value creation and business models. Ind. Manag. Data Syst. 2016, 116, 1820-1838. [CrossRef]

73. Dwivedi, A.; Johnson, L.W.; Wilkie, D.C.; De Araujo-Gil, L. Consumer emotional brand attachment with social media brands and social media brand equity. Eur. J. Mark. 2019, 53, 1176-1204. [CrossRef]

74. He, W.; Zhang, W.; Tian, X.; Tao, R.; Akula, V. Identifying customer knowledge on social media through data analytics. J. Enterp. Inf. Manag. 2019, 32, 152-169. [CrossRef]

75. Quesenberry, K.A. Social Media Strategy: Marketing, Advertising, and Public Relations in the Consumer Revolution; Rowman \& Littlefield Publishers: Lanham, MA, USA, 2020. 
76. Park, C.W.; MacInnis, D.J.; Eisingerich, A.B. Brand Admiration: Building a Business People Love; John Wiley \& Sons: Hoboken, NJ, USA, 2016.

77. Trivedi, J.; Sama, R. The effect of influencer marketing on consumers' brand admiration and online purchase intentions: An emerging market perspective. J. Internet Commer. 2020, 19, 103-124. [CrossRef]

78. Oliver, R.L. Whence consumer loyalty? J. Mark. 1999, 63, 33-44. [CrossRef]

79. Pérez, A.; del Bosque, I.R. Personal traits and customer responses to CSR perceptions in the banking sector. Int. J. Bank Mark. 2017, 35, 128-146. [CrossRef]

80. Nasrah, R. The Effect Of Experiential Marketing Toward Customer Loyalty (Empirical Study Of Fast Food Restaurants In Padang City). Int. J. Manag. Bus. 2020, 1, 104-110.

81. Han, H.; Yu, J.; Kim, W. Environmental corporate social responsibility and the strategy to boost the airline's image and customer loyalty intentions. J. Travel Tour. Mark. 2019, 36, 371-383. [CrossRef]

82. Ahmed, M.A.; Jouhar, R.; Ahmed, N.; Adnan, S.; Aftab, M.; Zafar, M.S.; Khurshid, Z. Fear and practice modifications among dentists to combat novel coronavirus disease (COVID-19) outbreak. Int. J. Environ. Res. Public Health 2020, 17, 2821. [CrossRef] [PubMed]

83. van Asperen, M.; de Rooij, P.; Dijkmans, C. Engagement-based loyalty: The effects of social media engagement on customer loyalty in the travel industry. Int. J. Hosp. Tour. Adm. 2018, 19, 78-94. [CrossRef]

84. Eisingerich, A.B.; Rubera, G.; Seifert, M.; Bhardwaj, G. Doing good and doing better despite negative information?: The role of corporate social responsibility in consumer resistance to negative information. J. Serv. Res. 2011, 14, 60-75. [CrossRef]

85. Sweetman, J.; Spears, R.; Livingstone, A.G.; Manstead, A.S. Admiration regulates social hierarchy: Antecedents, dispositions, and effects on intergroup behavior. J. Exp. Soc. Psychol. 2013, 49, 534-542. [CrossRef]

86. Dagger, T.S.; David, M.E.; Ng, S. Do relationship benefits and maintenance drive commitment and loyalty? J. Serv. Mark. 2011, 25, 273-281. [CrossRef]

87. Brown, T.A. Confirmatory Factor Analysis for Applied Research; Guilford Publications: New York, NY, USA, 2015.

88. Aramburu, I.A.; Pescador, I.G. The effects of corporate social responsibility on customer loyalty: The mediating effect of reputation in cooperative banks versus commercial banks in the Basque country. J. Bus. Ethics 2019, 154, 701-719. [CrossRef]

89. Bediako, B. The impact of corporate social responsibility on customer loyalty. A case study of StanBed Tours ky. Bus. Econ. 2017. [CrossRef]

90. Mercadé-Melé, P.; Molinillo, S.; Fernández-Morales, A.; Porcu, L. CSR activities and consumer loyalty: The effect of the type of publicizing medium. J. Bus. Econ. Manag. 2018, 19, 431-455. [CrossRef]

91. Nielsen, A.E.; Thomsen, C. CSR communication in small and medium-sized enterprises. Corp. Commun. Int. J. 2009, 14, 176-189. [CrossRef] 